\title{
Work Behavior from the Qur'anic Perspective
}

\author{
Ahmad Amri Zainal Adnan ${ }^{\mathrm{a}}$, Khairul Anwar Mastor ${ }^{\mathrm{b}}$, Hasnan Kasan ${ }^{\mathrm{c}}$, Firdaus Mohamad \\ Hamzah $^{\mathrm{d}}$ \\ ${ }^{a}$ Faculty of Management and Economics, Sultan Idris Education University, Malaysia, \\ a.amri@fpe.upsi.edu.my \\ ${ }^{b}$ Pusat Citra Universiti, National University of Malaysia, Malaysia, kam2000@ukm.edu.my \\ ${ }^{c}$ Pusat Citra Universiti, National University of Malaysia, Malaysia, hasnan@ukm.edu.my \\ ${ }^{d}$ Faculty of Engineering and Built Environment, National University of Malaysia, Malaysia,
} fmh@visi.eng.ukm.my

\begin{abstract}
The concept of work behaviour and its constructs derived from numerous approaches and disciplines. However, in the making of these work behavior constructs, religion has often been sidelined. Islamic management scholars have came up with Islamic work behavior theories according to the Qur'an and hadiths, but there is hardly enough empirical proof to support these theories. This paper aimed to determine the constructs of work behavior from the Qur'anic perspective using empirical method. The foundation of the constructs and items in the instrument are derived from the Qur'an and hadiths. A total of fifty-one items were extracted from verses of the Qur'an and hadiths. The content validity of the items were determined by consulting subject matter experts from the Faculty of Islamic Studies and Psychology, while factor analysis was used to analyse the reliability of the constructs. Data from respondents of a public university in Malaysia was analysed using principal component factor analysis. Six sub-constructs were extracted from two main constructs which are al-Qawiy (Ability) and al-Amin (Trustworthiness). The two main constructs have an alpha coefficient of .95 and .94 respectively. The al-Qawiy construct consists of three sub-constructs, which are Professional, Competent and Sensitive with alpha coefficient values of $.93, .90$ and .85 respectively. As for the al-Amin construct, which also consists of three subconstructs namely Integrity, Just and Principled, the alpha coefficient values are $.88, .89$ and .85 respectively. The outcome of this research proves that Islam integrates human nature and practical needs in a working surrounding across time. The output contributed to the literature of related research field such as the psychology of religion, organizational psychology and management, thus providing an alternative to assess Muslims' work behaviors with more reliability.
\end{abstract}

\section{Keywords:}

Work behavior, qur'anic perspective, religiosity

\section{INTRODUCTION}

This research was done to fill a gap that was left behind by researchers in the fields of management and organizational psychology, which is the integration of work behavior and religion from the Islamic perspective. This gap exist due to the fact that only a handful of scholars in this field recognized the role of religion in administration (King, 2007). Although the role of religion is recognized in society, management scholars still neglect religion in their research (Parboteah et al., 2009). Over the span of 25 years until 2015, only a handful of research concerning religiosity and work was done empirically with the use of tools that is based from the Qur'an and hadiths. Achour et al. (2015) for example, found that Islamic personal religiosity moderates the relationship between job strain and employee well-being amongs Muslim staff. They used a 21-item self report measurement tool that has been adapted from the Islamic perspectives. 
The literature concerning work behavior based on Islamic virtue is still limited (Junaidah Hashim, 2009) and the constructs of work behavior in an Islamic perspective is rarely discussed and studied (Syarifah Hayaati, 2010). Why does this area of research is considered important because previous research on work behavior that include Muslim samples did not assess their natural behaviors. This is due to the instruments that were used to assessed their work attitudes and behaviors did not take into account the fundamental concepts of work in the Islamic perspective such as working as an ibadah (worship) and the ultimate goal of achieving God's blessing in the hereafter through work (Mohd Affandi, 1992). Islamic management stands on the pillars of human values (Ahmad Ibrahim, 2002), whereas modern management theories separate values from work.

The western and modern perspectives of work behaviour are based on scientific and logic alone. As said by Ahmad Ibrahim (2002), the basis of western concept of management is through cognitive reasoning. Approach derived from theories such as humanisme and behaviorisme exclude the importance of religion and values. Three main concepts that are widely use in discussing work behaviour are job satisfaction, organizational commitment and job involvement. These concepts evolve around interaction between human and its surrounding in the workplace to achieve organization's objectives. Most research in the topic of work behaviour almost entirely neglect the effects of religiosity towards behavior.

In an Islamic perspective, thoughts on management are directly based on the Qur'an and hadiths of the prophet Muhammad (pbuh) (Ahmad Ibrahim, 2002). Definition of work behavior in an Islamic perspective can best be described as behaviors that are related to work and are done in conscious of and abide to the virtues and principles stated in the Qur'an and hadiths. Beside noble virtues and attitudes, Islam also focuses on the abilities and skills of a worker (Nik Mustapha, 2003). Unfortunately, most instruments available nowadays that are meant to assess work attitude or behavior do not comply to the fundamentals of Islam. In this study, behaviour constructs were developed based on the Qur'an dan hadiths to achieve reliability in Muslim's work behaviour assessment in future research.

\section{METHODS}

The research uses a deductive approach, in which data were collected via questionnaires. Purposive sampling method was used to achieve criterion validity. The respondents were management officers from a public university in Malaysia. Permission from the Head of Human Resource Division was granted and sets of questionnaires were given to all 183 management officers in the university. From the total of 183 questionnaires, 100 were eligible for analysis.

The main constructs of Islamic work behaviour were derived directly from the Qur'an. The Qur'an mentioned characteristics of the best worker in the 26th verse of surah al-Qasas: "And said one of them (the two women): "O my father! Hire him! Verily, the best of men for you to hire is the strong (al-Qawiy), the trustworthy (al-Amin)".

Al-Qawiy and al-Amin were translated by Islamic scholar as strength and trustworthiness (al-Qaradawi, 2002). Al-Qawiy is related to competency, capable to execute a job efficiently by having talent, knowledge and ability; while al-Amin is having a sense of fear towards Allah in every action taken. In modern terms, al-Amin can also be define as integrity (Kamar Oniah \& Abdul Razak, 2011). The shaping of the Muslim Work Behavior started from the identification of sub-constructs to the two main constructs, al-Qawiy and alAmin, that was obtained from the Quran, hadiths and Islamic scholars. 
Sub-constructs were also strengthen by an interview session with a high profile administrator of a higher learning institute in Malaysia. She was chosen to be the subject expert mainly because of her excellence throughout her career as a Registrar at the university and her achievements at the national level as a public university administrator. The items then were referred to experts, each specialized in psychology and Islamic study to get the face validity and content validity. The experts were given a set of documents that contains information on the constructs, sub-constructs and items. They were asked to give their assessment on the items in a scale of one to three, one is 'not accurate', two is 'less accurate', and three is 'accurate'.

The five option Likert scale questionnaires were administrated to respondents from a public university in Malaysia. The data obtained were used to clarified the inter-item correlation. Exploratory factor analysis with principal component and varimax rotation methods was run several times to the items from each construct to gain the best output in terms of the value of Cronbach alpha and exact sub-constructs.

A total of 24 sub-constructs have been identified. Nine sub-constructs were extracted from al-Amin construct and 15 sub-constructs were extracted from al-Qawiy. The subconstructs for al-Qawiy are Commitment, Accountability, Responsibility, Wise, Motivated, Competitive, Skillful, Self-image, Effective, Efficient, Productive, Quality, Empathy, Responsive, and Innovative. The nine sub-constructs for al-Amin are Honesty, Sincere, Grateful, Altruistic, Principled, Transparent, Just, Fear of God, and Integrity.

The Qur'an and hadith were used as the main references in the extraction of items to ensure that the items truly reflect the sub-constructs. Items in the form of sentences were built based on two methods. First, it is based on the essence of the verses of Qur'an and hadiths. Second, it was based on the reality of behavior in the workplace. Both methods were done carefully so that it strictly assess human behaviors only. A total of 51 items were extracted.

\section{RESULTS AND DISCUSSION}

Bartlett's Test of Sphericity for both constructs shows $\mathrm{p}<.05$, thus inter-item correlation is sufficient to conduct factor analysis. The value for Kaiser-Meyer-Olkin Measure of Sampling Adequacy (KMO) is larger than .50, showing no multicollinearity issue. Three main factors were extracted from al-Qawiy using factor analysis with an alpha value of $.93, .90$ and .83 respectively. Three components with an eigen value of greater than 1.0 were extracted, which explained $59.97 \%$ of the total varians. The scree plot graph in Table 1 shows the three main components that contribute to the total varians in al-Qawiy.

All of the items were catagorised into three factors with loading values of more than .33. Factor one contains 15 items, factor two contains nine items and factor three contains five items. Two items were dismissed from al-Qawiy construct because the cross-loading between sub-constructs are more than .50 . Cronbach reliability test of the construct after the two items were remove shows a value of .96 .

Analysis result of Al-Amin construct also produced three factors with an alpha value of $.89, .88$ and .85 . Components with an eigen value more than 1.0 explained $61.71 \%$ of the total varians. All items in the construct with factor loading more than .33 are catagories into three factors. Factor one consists of nine items, factor two consists of eight items, and factor three consists of five items (Refer to Table 2). One item was dismissed from al-Amin 
construct because the cross-loading value is more than .5. Cronbach alpha reliability test after the item was dismissed shows a value of .94 .

Table 1: Output of exploratory factor analysis for al-Qawiy construct

\begin{tabular}{|c|c|c|c|}
\hline No. Item & 1 & 2 & 3 \\
\hline ITEM12 & .806 & & \\
\hline ITEM11 & .732 & & \\
\hline ITEM1 & .730 & & \\
\hline ITEM9 & .720 & & \\
\hline ITEM7 & .668 & & \\
\hline ITEM2 & .640 & & \\
\hline ITEM5 & .638 & & \\
\hline ITEM10 & .610 & & \\
\hline ITEM37 & .592 & & \\
\hline ITEM6 & .569 & & \\
\hline ITEM4 & .567 & & \\
\hline ITEM15 & .533 & & \\
\hline ITEM38 & .532 & & \\
\hline ITEM8 & & .433 & \\
\hline ITEM27 & & .441 & \\
\hline ITEM32 & & .781 & \\
\hline ITEM29 & & .694 & \\
\hline ITEM30 & & .692 & \\
\hline ITEM33 & & .662 & \\
\hline ITEM35 & & .660 & \\
\hline ITEM31 & & .600 & \\
\hline ITEM26 & & .581 & \\
\hline ITEM25 & & .575 & \\
\hline ITEM34 & & .569 & \\
\hline ITEM14 & & & .818 \\
\hline ITEM36 & & & .787 \\
\hline ITEM13 & & & .785 \\
\hline ITEM3 & & & .586 \\
\hline ITEM28 & & & .580 \\
\hline
\end{tabular}

$\mathrm{n}=100, \mathrm{p}<0.001$

Overall, six factors were successfully extracted from the two main constructs, al-Qawiy (Strength) and al-Amin (Trustworthiness). The two main constructs have an alpha coefficient of .96 and .94. The Al-Qawiy construct consists of three factors, namely Professional, Competent and Sensitive with an alpha coefficient value of $.93, .90$ and .85 respectively. As for the al-Amin construct, it also consists of three factors namely Integrity, Just and Principled with an alpha coefficient value of $.88, .89$ and .85 respectively. 
Table 2: Output of exploratory factor analysis for al-Amin construct

\begin{tabular}{llll}
\hline No. Item & 1 & 2 & 3 \\
\hline ITEM24 & .758 & & \\
ITEM46 & .737 & & \\
ITEM23 & .697 & & \\
ITEM19 & .645 & & \\
ITEM18 & .625 & & \\
ITEM40 & .594 & & \\
ITEM47 & .573 & & \\
ITEM41 & .525 & .806 & .862 \\
ITEM16 & .487 & .759 & .721 \\
ITEM42 & & .682 & .655 \\
ITEM39 & .669 & .576 \\
ITEM22 & .655 & .488 \\
ITEM50 & & .635 & \\
ITEM45 & & .606 & \\
ITEM48 & & .545 & \\
ITEM49 & & & \\
ITEM43 & & \\
ITEM21 & & \\
ITEM51 & & & \\
ITEM17 & & & \\
ITEM20 & & & \\
ITEM44 & & & \\
\hline
\end{tabular}

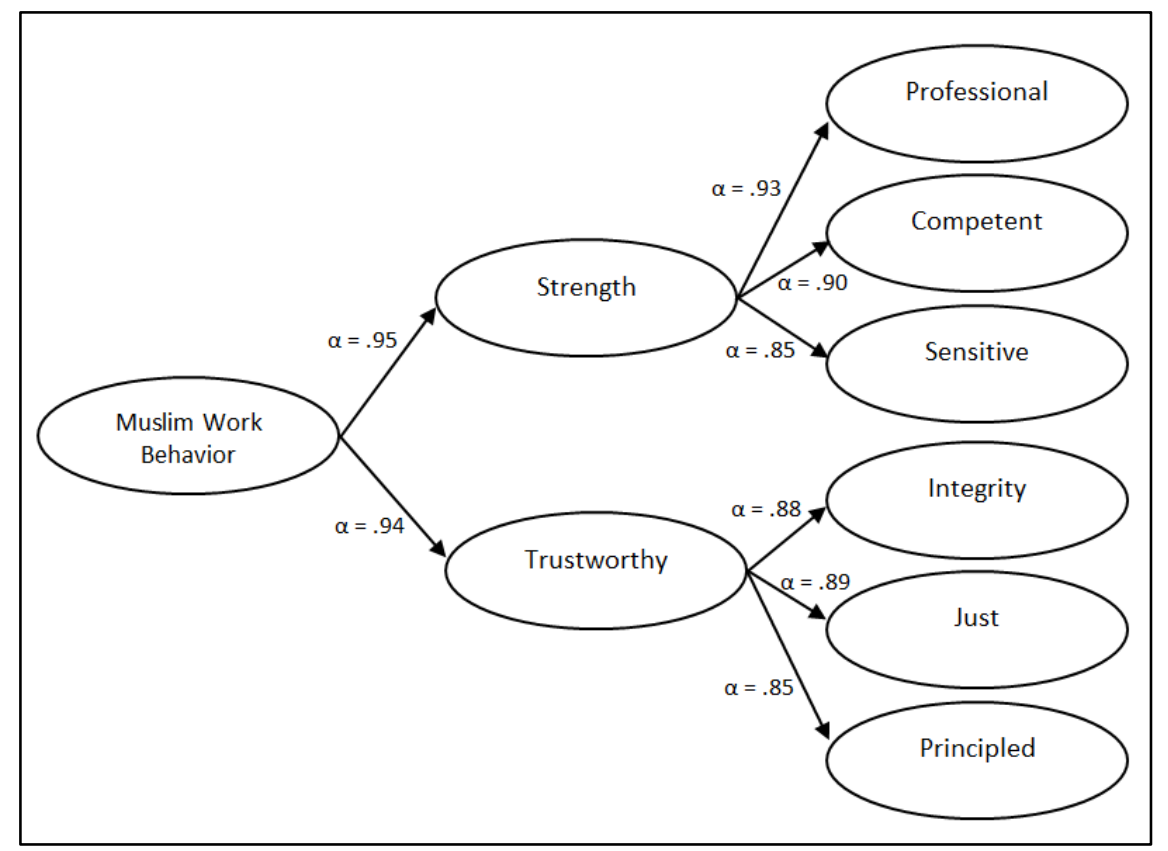

Figure 1: Constructs and sub-constructs of Muslim's Work Behavior 
The study confirmed that Muslim's work behavior can be extracted from the Qur'an and hadiths. The constructs and sub-constructs in this study obtained significant validity and reliability both empirically and rationally, thus is more suitable for assessing work behavor in a Muslim samples. The outcome of this research also shows that by extracting constructs from a reliable source (in accordance to religion) using deductive approach gives meaning to the concept of work behavior. Unlike western perspective of work behavior, the Islamic perspective of work behavior is inclusive of internal (values) and external (competency) elements, worldly and hereafter.

The study used sample from only one line of work, that is management and administration from the public sector. Due to this niche, the assessment tool is more suitable for public administration sector and may not be suitable for use by other line of jobs such as police officer or teacher. The items also concentrates solely on the behavioral aspect of a worker and exclude the cognitive and affective aspects of a worker.

The constructs and sub-constructs that have been extracted from the Qur'an and validated by statistical method gave an insight of the main pillars of Islamic work behavior that every employer can focused in developing human resource. While results are encouraging, further confirmatory analysis should be conduct on different work samples. In addition, multiple methods of research should be used to cross-validate these measures, including employee interview.

\section{CONCLUSION}

From this research, we conclude that there are two main constructs in a Muslim work behavior, which is Strength (al-Qawiy) and Trustworthiness (al-Amin); and six sub-constructs which is Professional, Competent, Sensitive, Integrity, Just and Principled. The outcome of this research proves that Islam integrates human nature and practical needs in a working surrounding across time. The truth of this claim is mention in the second verse of surah $\mathrm{Al}$ Baqarah in the Qur'an: "This Book, there is no doubt in it, is a guide to those who guard (against evil)."

The output contributed to the literature of related research field such as the psychology of religion, organizational psychology and management, thus providing an alternative to assess Muslims' work behaviors more realistically.

\section{REFERENCES}

Achour, M., Mohd Roslan, M.N. \& Zulkifli, M.Y. M.Y. (2015). Islamic personal religiosity as a moderator of job strain and employee's well-being: the case of Malaysian academic and administrative staff. Journal of Religion and Health.

Ahmad Ibrahim Abu Sin. (2002). Pengurusan dalam Islam (3 ${ }^{\text {rd }}$ ed.). (Abu Rashid Ngah \& Jusoh Kadir, Trans.). Kuala Lumpur: Dewan Bahasa dan Pustaka.

Junaidah Hashim. 2009. Islamic revival in human resource management practices among selected Islamic organizations in Malaysia. International Journal of Islamic and Middle Eastern Finance and Management 2(3): 251-267. 
Kamar Oniah Kamaruzaman \& Abdul Razak Abdullah Hashi. (2011). Managerial Ethics of Public Administrators From The Qur'anic Perspective. In Khaliq Ahmad, Rafikul Islam \& Yusof Ismail (Eds.). Issues in Islamic Management: Theories and Practices. Kuala Lumpur: IIUM Press.

King, S.M. (2007). Religion, spirituality, and the workplace: challenges for the public administration. Public Administration Review 67(1): 103-114.

Mohd Affandi Hassan. (1992). The Tauhidic Approach in Management: Concepts, Principles and An Alternative Model. Kuala Lumpur: National Institute of Public Administration (INTAN).

Nik Mustapha Nik Hassan. (2003). Falsafah Pengurusan dan Pentadbiran dalam Islam. In Syed Othman Alhabshi \& Hamiza Ibrahim (Eds.). Pengurusan dan Pentadbiran: Mencapai Kecemerlangan Melalui Penghayatan Nilai ( $3^{\text {rd }}$ ed.). Kuala Lumpur: Institut Kefahaman Islam Malaysia (IKIM).

Parboteeah, K.P., Hoegl, M. \& Cullen, J. (2009). Religious dimensions and work obligation: a country institutional profile model. Human Relations 62(1):119-148.

Sharifah Hayaati Ismail al-Qudsy. (2010). Etika Penjawat Awam dari Perspektif Islam. Dewan Bahasa dan Pustaka: Kuala Lumpur.

Yusuf al-Qaradawi. (2002). Al-Sahwah al-Islamiah min al-Murahaqah ila al-Rusyd. Kaherah: Dar alSyuruq. 